\title{
Evaluation and Management of the Patient with Pulmonary Arterial Hypertension
}

Lewis J. Rubin, MD, and David B. Badesch, MD

Increased pressure in the pulmonary circulation, or pulmonary hypertension, is a common disorder that may complicate various cardiopulmonary conditions, including severe obstructive airways disease and left ventricular dysfunction. An increase in pulmonary arterial pressure that is not due to coexistent cardiopulmonary disease, known as pulmonary arterial hypertension, may occur in the absence of a demonstrable cause (idiopathic or familial); as a complication of systemic conditions, such as connective tissue disease, HIV infection, or chronic liver disease; or as a result of the use of fenfluramine anorexigens, amphetamines, or cocaine. The development of disease-specific therapies for pulmonary arterial hypertension over the past decade underscores the importance of diagnosing pulmonary hypertension early in the course of the condition and implementing a treatment strategy that is based on the condition's cause and severity. In this review, the authors present approaches to the diagnosis and management of pulmonary arterial hypertension, using a hypothetical case to highlight the key management points.

Ann Intern Med. 2005;143:282-292.

For author affiliations, see end of text. www.annals.org
U ntil recently, management of pulmonary arterial hypertension $(\mathrm{PAH})$ was generally ineffective in alleviating symptoms or improving survival. However, the past decade has witnessed remarkable advances in our understanding of the pathogenesis of $\mathrm{PAH}$, advances that have led to the development of disease-specific treatments. Despite these achievements, $\mathrm{PAH}$ remains a challenging condition to diagnose and manage. This article reviews recent developments in the diagnosis and management of PAH in the context of a typical case, illustrating the importance of collaboration between the internist and the specialist in patient care.

A 33-year-old woman presented to her primary care physician with a 6-month history of gradually progressive exertional dyspnea. She had lightheadedness and near-syncope while climbing steps. She was mildly obese but had otherwise previously been in good health. Her vital signs were normal, her lungs were clear, and cardiac examination showed a slightly prominent second heart sound and a systolic murmur over the left-heart border. An initial diagnosis of exercise-induced asthma was made, and use of an inhaled bronchodilator was prescribed.

The patient's symptoms did not diminish. A chest radiograph showed mild cardiomegaly and a slightly prominent main pulmonary artery. Pulmonary function tests showed only a mild reduction in the diffusing capacity for carbon monox$i d e$, and an electrocardiogram showed right-axis deviation and possible right ventricular hypertrophy. On the basis of these results, echocardiography was done, and the echocardiogram showed right ventricular hypertrophy, right atrial enlargement, flattening of the interventricular septum, and moderate tricuspid regurgitation with an estimated pulmonary artery systolic pressure of $60 \mathrm{~mm} \mathrm{Hg}$. Serologic test results did not suggest connective tissue disease. A ventilation-perfusion lung scan was normal. Overnight oximetry showed mild nocturnal oxygen desaturation, and a formal sleep study excluded sleep apnea syndrome. The patient was referred to a regional center with a provisional diagnosis of pulmonary hypertension.

\section{What Is Pulmonary Hypertension, and When Is It Considered To Be Present?}

Pulmonary hypertension is an elevation in pulmonary vascular pressure that can be caused by an isolated increase in pulmonary arterial pressure or by increases in both pulmonary arterial and pulmonary venous pressures. The term pulmonary arterial hypertension refers to conditions that share common isolated elevations in pulmonary arterial pressure (Table 1), hemodynamically defined as a resting mean pulmonary arterial pressure greater than $25 \mathrm{~mm} \mathrm{Hg}$ with a normal pulmonary capillary or left atrial pressure $(<15 \mathrm{~mm} \mathrm{Hg})(1,2)$. Pulmonary arterial hypertension that occurs without a demonstrable cause, formerly known as primary pulmonary hypertension, may occur sporadically (idiopathic PAH) or as an inherited condition (familial PAH). Mutations in the bone morphogenetic protein receptor II gene occur in approximately $50 \%$ of families with a history of familial PAH and in nearly $25 \%$ of patients believed to have sporadic idiopathic PAH $(3,4)$. Genetic testing and counseling have been recommended for relatives of patients with familial PAH (4). Pulmonary arterial hypertension occurs in association with connective tissue diseases, particularly scleroderma (5-9); HIV infection (10-12); sickle-cell disease (13); and chronic liver disease $(14,15)$. Pulmonary hypertension is suggested when an echocardiogram-derived estimate of pulmonary arterial systolic pressure exceeds $40 \mathrm{~mm} \mathrm{Hg}$ at rest.

See also:

Web-Only

CME quiz

Conversion of figure and tables into slides 


\section{When Should PAH Be Suspected?}

Although PAH may be asymptomatic, exertional dyspnea is the most frequently encountered symptom (16). Accordingly, PAH should be suspected in patients with unexplained dyspnea. Angina or syncope is less common and portends a poor prognosis. Peripheral edema or ascites indicates right ventricular failure. The symptoms of PAH are nonspecific and are similar to those in more common diseases, such as obstructive lung disease and left-sided heart disease.

A family history of pulmonary hypertension may lead to early recognition of clinical disease in other persons (17). A history of use of fenfluramine appetite suppressants $(18,19)$ and current or previous use of amphetamines or cocaine should be explored, because these factors have been implicated in the development of PAH in some users. A history of acute pulmonary embolism requires a careful search for chronic thromboembolic pulmonary hypertension, although this condition may occur in the absence of symptomatic venous thromboembolic disease (20).

\section{When PAH Is Suspected, How Do You Confirm the Diagnosis and Establish a Cause?}

The diagnostic strategy systematically uses testing to determine whether the patient's symptoms are due to PAH and, if so, the underlying cause (Figure). Screening with less invasive, less complex, and lower-risk tests is followed by specific and direct confirmatory tests.

The electrocardiogram may provide evidence of hemodynamically significant pulmonary hypertension, such as right ventricular hypertrophy, right-axis deviation, or right atrial enlargement. Radiographic signs of pulmonary hypertension include enlarged main and hilar pulmonary arterial shadows $(>17 \mathrm{~mm})$ with attenuation of peripheral pulmonary vascular markings (pruning). Right ventricular enlargement is evidenced by anterior displacement of the right ventricle into the retrosternal space on the lateral view. The chest radiograph is also useful in showing comorbid or causal conditions, such as pulmonary venous congestion, chronic obstructive pulmonary disease, or interstitial lung disease.

Doppler echocardiography is often the first test with results that suggest a diagnosis of pulmonary hypertension (21). Echocardiography also provides information about the cause and consequences of pulmonary hypertension. Studies in patients with PAH (22-25) have reported good correlations between Doppler-derived estimates of pulmonary arterial systolic pressure and direct measurements obtained by right-heart catheterization. Echocardiography also provides direct evidence about left ventricular systolic and diastolic function, as well as valvular function and morphologic characteristics that can give clues to causes of pulmonary hypertension due to elevated pulmonary venous pressures. Left atrial enlargement, even in the absence of definite left ventricular dysfunction, should raise the
Table 1. Nomenclature and Classification of Pulmonary Hypertension*

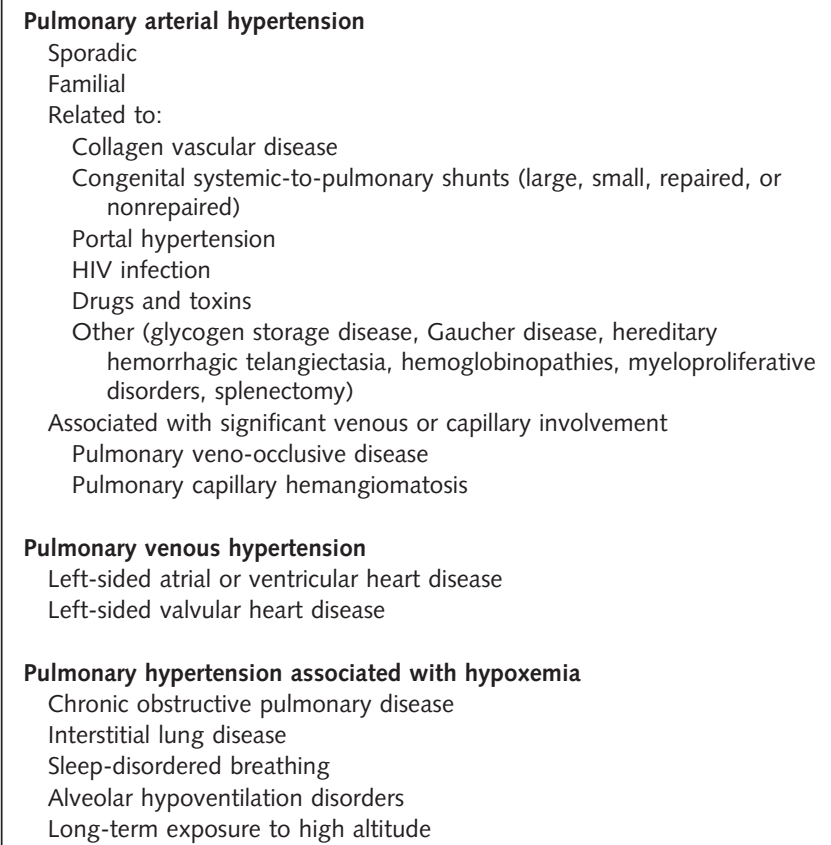

Pulmonary hypertension due to chronic thrombotic or embolic disease Thromboembolic obstruction of proximal pulmonary arteries Thromboembolic obstruction of distal pulmonary arteries Pulmonary embolism (tumor, parasites, foreign material)

Miscellaneous

Sarcoidosis, histiocytosis $\mathrm{X}$, lymphangiomatosis, compression of pulmonary vessels (adenopathy, tumor, fibrosing mediastinitis)

* Adapted with permission from reference 1. This classification schema was based on one proposed at the 3rd World Conference on Pulmonary Hypertension, Venice, Italy, 2003.

possibility of elevated left-sided filling pressures that may contribute to pulmonary hypertension.

The evaluation of PAH includes assessment for an underlying autoimmune-collagen vascular disorder, including physical examination and serologic testing for antinuclear antibodies. However, as many as $40 \%$ of patients with idiopathic PAH have serologic abnormalities (16), usually an antinuclear antibody in a low titer and nonspecific pattern. Additional serologic studies may be appropriate if initial testing suggests an underlying autoimmune disorder.

Pulmonary function testing is necessary in the initial evaluation of patients with suspected pulmonary hypertension, primarily to exclude or characterize the contribution of underlying airways or parenchymal lung disease. In general, the degree of pulmonary hypertension in patients with chronic obstructive lung disease is less severe than that in patients with $\mathrm{PAH}$, and the presence and severity of pulmonary hypertension correlate with the degree of airflow obstruction and hypoxemia. Approximately $20 \%$ of patients with idiopathic PAH have a mild restrictive defect (16). In chronic thromboembolic pulmonary hypertension, 
REVIEW Evaluation and Management of the Patient with Pulmonary Arterial Hypertension

Figure. Guideline for approaching the differential diagnosis of pulmonary hypertension $(\mathrm{PH})$.

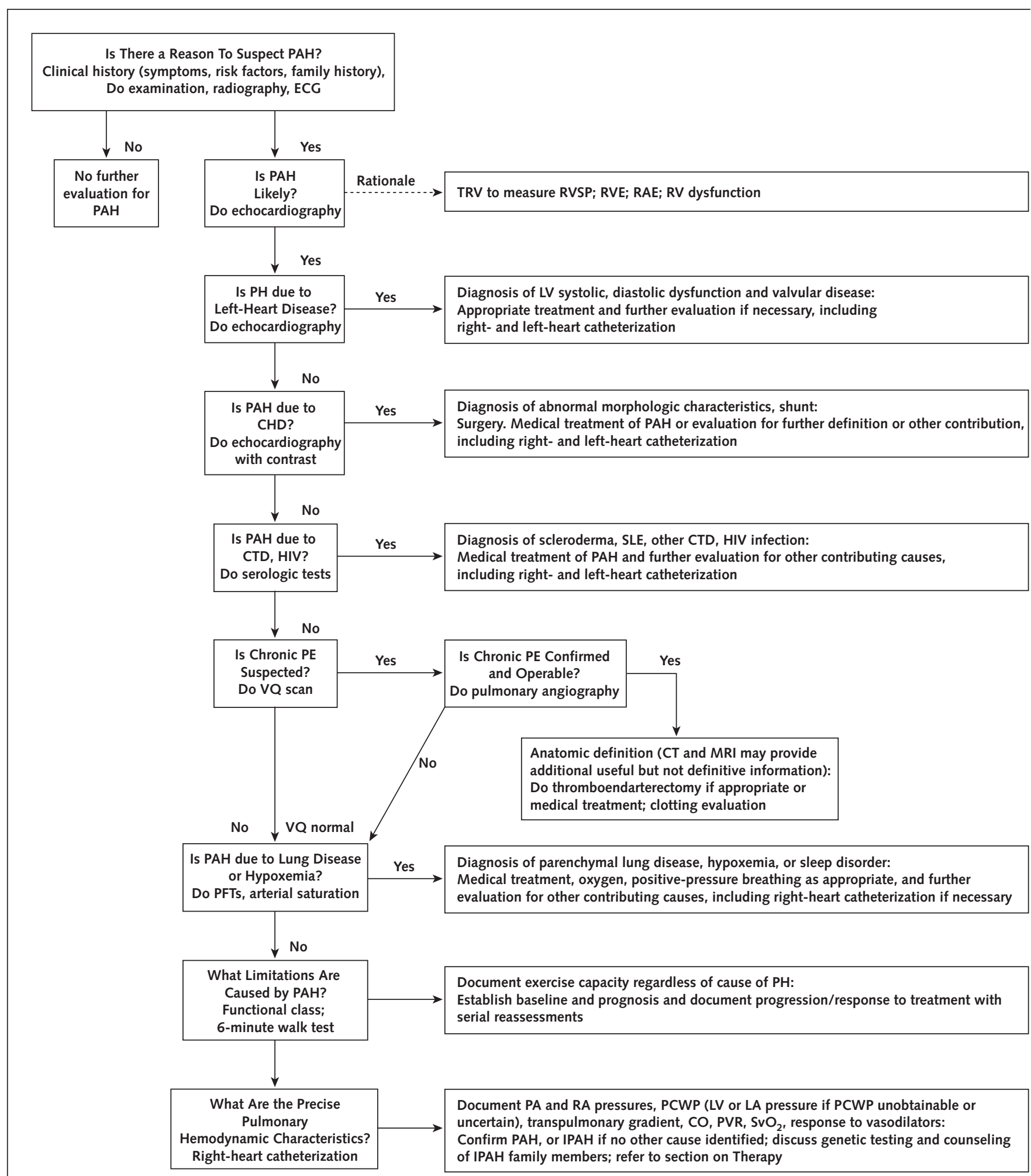

$\mathrm{CHD}=$ congenital heart disease; $\mathrm{CO}=$ cardiac output; $\mathrm{CT}=$ contrast-enhanced computed tomography of the chest; CTD = connective tissue disease; $\mathrm{ECG}=$ electrocardiogram; Echo $=$ Doppler transthoracic echocardiogram; IPAH = idiopathic pulmonary arterial hypertension; LA = left atrial; LV = left ventricular; $\mathrm{MRI}=$ magnetic resonance imaging; $\mathrm{PA}=$ pulmonary arterial; $\mathrm{PAH}=$ pulmonary arterial hypertension; $\mathrm{PCWP}=$ pulmonary capillary wedge pressure; $\mathrm{PE}=$ pulmonary embolism; $\mathrm{PFTs}=$ pulmonary function tests; $\mathrm{PVR}=$ pulmonary vascular resistance; $\mathrm{RA}=$ right atrial; $\mathrm{RAE}=$ right atrial enlargement; RV = right ventricular; RVE = right ventricular enlargement; RVSP = right ventricular systolic pressure; SLE = systemic lupus erythematosus; $\mathrm{SvO}_{2}=$ mixed venous oxygen saturation; TRV = tricuspid regurgitant velocity; VQ = ventilation-perfusion. (Adapted with permission from reference 1. .) 
a mild to moderate restrictive defect is thought to be due to parenchymal scarring from previous infarctions (26). In both conditions, the diffusing capacity for carbon monoxide is often mildly to moderately reduced $(16,26)$. Mild to moderate arterial hypoxemia is due to ventilation-perfusion mismatch and reduced mixed venous oxygen saturation resulting from low cardiac output. Severe hypoxemia is due to right-to-left intracardiac or intrapulmonary shunting. Twenty percent of patients with systemic sclerosis have an isolated reduction in diffusing capacity (27); a diffusing capacity less than $45 \%$ to $55 \%$ of predicted or one that is decreasing may signal the development of pulmonary hypertension (28).

Overnight oximetry may show frequent desaturations and may be the first clue to sleep apnea sufficient to contribute to pulmonary hypertension. Nocturnal hypoxemia occurs in more than $75 \%$ of patients with idiopathic $\mathrm{PAH}$ without sleep apnea (29). Because hypoxemia is a potent pulmonary vasoconstrictor, all patients with unexplained pulmonary hypertension require assessment of oxygen saturation during both sleep and exercise (30).

Chronic thromboembolic pulmonary hypertension is potentially curable and should be sought in all patients with pulmonary hypertension. Ventilation-perfusion lung scanning is the preferred test to evaluate for this condition (4). Chronic thromboembolic pulmonary hypertension manifests as at least 1 segmental-sized or larger perfusion defect, which is typically mismatched and larger than ventilation abnormalities $(20,31,32)$. Patchy, nonsegmental defects are less specific but may be associated with chronic thromboembolic pulmonary hypertension. Perfusion scans tend to underestimate the extent of large-vessel obstruction in this condition (32). Although a normal perfusion scan essentially excludes surgically accessible chronic thromboembolic disease, scans suggestive of thromboembolic disease may also be seen in patients with pulmonary arterial sarcoma, large-vessel pulmonary arteritis, extrinsic vascular compression, or pulmonary veno-occlusive disease (33). Pulmonary angiography is the definitive test for diagnosing chronic thromboembolic pulmonary hypertension and determining operability, and it should be done in experienced centers when chronic thromboembolic pulmonary hypertension remains possible.

Computed tomographic scanning may suggest a cause of PAH, such as severe airway or parenchymal lung diseases. A spectrum of abnormalities on computed tomographic scans has been described in chronic thromboembolic pulmonary hypertension, including right ventricular enlargement, dilated central pulmonary arteries, chronic thromboembolic material within the central pulmonary arteries, increased bronchial artery collateral flow, variability in the size and distribution of pulmonary arteries, parenchymal abnormalities consistent with previous infarctions, and mosaic attenuation of the pulmonary parenchyma (34). A ground-glass, mosaic-attenuation pattern predom- inantly in the lower lobes is also suggestive of pulmonary veno-occlusive disease (35).

Cardiac catheterization is ultimately required to confirm the presence of pulmonary hypertension, definitively establish its cause, assess severity, and guide therapy. Open or thoracoscopic lung biopsy entails substantial risk for hemorrhage, hypoxemia, and death in patients with PAH. Because it has a low likelihood of altering the clinical diagnosis, routine biopsy is discouraged. Under certain circumstances, histopathologic diagnosis may be needed when vasculitis, granulomatous or interstitial lung disease, pulmonary veno-occlusive disease, or bronchiolitis are suggested clinically (36).

Initial evaluation at the referral center included a 6-min walk test of $305 \mathrm{~m}$. Right-heart catheterization showed a pulmonary arterial pressure of $65 / 30 \mathrm{~mm} \mathrm{Hg}$ (mean, $42 \mathrm{~mm}$ $\mathrm{Hg}$ ), right atrial pressure of $12 \mathrm{~mm} \mathrm{Hg}$, pulmonary capillary wedge pressure of $6 \mathrm{~mm} \mathrm{Hg}$, and cardiac output of $3.2 \mathrm{~L} / \mathrm{min}$. Little change was seen in hemodynamic measurements with the inhalation of nitric oxide. The patient was thought to have idiopathic PAH, falling into New York Heart Association (NYHA) functional class III on the basis of her symptoms. Treatment options were discussed with the patient and her family. Medical therapy, diet, exercise, travel, altitude exposure, and pregnancy were all discussed.

There are few data on which to base recommendations about physical activity or cardiopulmonary rehabilitation in patients with PAH. Potentially hazardous exposure activities are listed in Table 2 . We encourage cautious, graduated physical activity. Heavy physical activity can precipitate exertional syncope. Hot baths or showers are discouraged because the resultant peripheral vasodilatation can produce systemic hypotension and syncope. Excessive sodium intake can contribute to fluid retention.

We discourage exposure to high altitudes (more than approximately $1800 \mathrm{~m}$ above sea level), as this may produce hypoxic pulmonary vasoconstriction and further compromise oxygen transport. Supplemental oxygen should be used to maintain oxygen saturations greater than $91 \%$. Air travel can be problematic for patients with PAH, as commercial aircraft are typically pressurized to the equivalent of approximately $2400 \mathrm{~m}$ above sea level. While on commercial aircraft, patients who have borderline oxygen saturations at sea level may require 3 to $4 \mathrm{~L} / \mathrm{min}$ of supplemental oxygen, and those already using supplemental oxygen at sea level should increase their oxygen flow rate. Because of the potentially devastating effects of respiratory infections, immunization against influenza and pneumococcal pneumonia is recommended.

The hemodynamic changes occurring during pregnancy impose substantial stress in women with PAH, leading to a $30 \%$ to $50 \%$ mortality rate $(37,38)$. Although successful use of long-term intravenous epoprostenol and inhaled nitric oxide to treat pregnant patients with idio-

16 August 2005 |Annals of Internal Medicine $\mid$ Volume 143 • Number $4 \mid 285$ 
REviEW Evaluation and Management of the Patient with Pulmonary Arterial Hypertension

Table 2. Potentially Hazardous Activities for Patients with Pulmonary Arterial Hypertension

\begin{tabular}{|c|c|c|}
\hline Activity & Potential Adverse Effects & Recommendations \\
\hline Exposure to high altitude & $\begin{array}{l}\text { Hypoxemia, pulmonary vasoconstriction, } \\
\text { worsening pulmonary hypertension, } \\
\text { right-heart failure }\end{array}$ & $\begin{array}{l}\text { Avoid altitudes }>1800 \mathrm{~m} \text { above sea level; use } \\
\text { supplemental oxygen as needed to keep } \\
\text { oxygen saturation } \geq 91 \% \text { at all times }\end{array}$ \\
\hline Air travel & $\begin{array}{l}\text { Hypoxemia, pulmonary vasoconstriction, } \\
\text { worsening pulmonary hypertension }\end{array}$ & $\begin{array}{l}\text { Use supplemental oxygen as needed to keep } \\
\text { oxygen saturation } \geq 91 \% \text { at all times }\end{array}$ \\
\hline Heavy exertion & Near-syncope, syncope & $\begin{array}{l}\text { Engage in low-level activity or cautious, } \\
\text { graduated exercise, such as walking }\end{array}$ \\
\hline Bending over and rising quickly & Near-syncope, syncope & $\begin{array}{l}\text { Rise slowly from bending, sitting, or lying } \\
\text { positions }\end{array}$ \\
\hline Use of decongestant medications & $\begin{array}{l}\text { Vasoconstriction, worsening pulmonary } \\
\text { hypertension }\end{array}$ & $\begin{array}{l}\text { Avoid using decongestants; consider nonsedating } \\
\text { antihistamines or local treatments, such as } \\
\text { nasal steroids }\end{array}$ \\
\hline Use of appetite suppressants or diet pills & Worsening pulmonary hypertension & $\begin{array}{l}\text { Have dietary and nutritional consultation; } \\
\text { engage in cautious low-level exercise }\end{array}$ \\
\hline High sodium intake & Fluid retention, right-heart failure & Follow 2-g sodium diet \\
\hline Cigarette smoking & $\begin{array}{l}\text { Worsening of intrinsic lung disease; nicotine } \\
\text { is a vasoconstrictor and may contribute } \\
\text { to worsening pulmonary hypertension }\end{array}$ & $\begin{array}{l}\text { Stop smoking (preferably without use of nicotine } \\
\text { replacement therapy) }\end{array}$ \\
\hline
\end{tabular}

pathic PAH has been reported (39-42), most experts recommend early termination of the pregnancy (43).

Estrogen-containing contraceptives may increase risk for venous thromboembolism and are not recommended for women of childbearing potential with PAH. Also, the endothelin-receptor antagonist bosentan may decrease the efficacy of hormonal contraception, and dual mechanical barrier contraceptive techniques are recommended in women of childbearing age using this medication.

Physicians should discuss with their patients the use of any concomitant medications or herbal preparations. The use of vasoconstricting sinus or cold medications (such as pseudoephedrine) or the use of serotonergic medications for migraine headaches may be problematic. Concomitant use of glyburide or cyclosporine with bosentan is contraindicated, and use of azole-type antifungal agents is discouraged because of potential drug interactions that may increase risk for hepatotoxicity. Patients using warfarin should be cautioned about the many drug interactions possible with this medication. Bosentan may slightly decrease international normalized ratios in patients using warfarin.

Invasive procedures and surgery can be associated with increased operative and perioperative risks. Patients with severe $\mathrm{PAH}$ are especially prone to vasovagal events leading to syncope, cardiopulmonary arrest, and death. Cardiac output is particularly dependent on heart rate in this setting, and the bradycardia and systemic vasodilatation accompanying a vasovagal event can result in hypotension. Heart rate should be monitored during invasive procedures, and an anticholinergic agent should be readily available. Oversedation can lead to ventilatory insufficiency and precipitate clinical deterioration. Caution should be used with laparoscopic procedures in which carbon dioxide is used for abdominal insufflation, as absorption can produce hypercarbia, which is a pulmonary vasoconstrictor. Anesthesia and intubation can be particularly problematic because they can induce vasovagal events, hypoxemia, hyper- carbia, and shifts in intrathoracic pressure and associated changes in cardiac filling pressures.

\section{What Are the Treatments for PAH, and How Does One Choose and Monitor Therapy?}

Medical therapy for PAH has recently been addressed in detail in 2 major consensus documents $(43,44)$ that use similar evidence-based therapeutic algorithms.

\section{General Measures}

Two small retrospective studies $(45,46)$ reported improved survival with oral anticoagulation in patients with idiopathic PAH. On the basis of these reports and the knowledge that microscopic in situ thrombosis can occur, anticoagulation with warfarin is recommended. Although little evidence is available to guide such therapy, current consensus suggests a target international normalized ratio of approximately 1.5 to $2.5(43,44)$. Anticoagulation is controversial for patients who have PAH due to other causes, such as scleroderma or congenital heart disease, because of a lack of evidence supporting efficacy, an increased risk for gastrointestinal bleeding in patients with scleroderma, and an increased risk for hemoptysis in patients with congenital heart disease. The relative risks and benefits of anticoagulant therapy should be considered on a case-by-case basis. Patients with documented right-to-left intracardiac shunting due to an atrial septal defect or patent foramen ovale and a history of transient ischemic attack or embolic stroke should receive anticoagulation. Patients treated with long-term intravenous epoprostenol generally receive anticoagulation in the absence of contraindications, partly because of the additional risk for catheter-associated thrombosis.

Diuretics are indicated for right ventricular volume overload. However, rapid and excessive diuresis may precipitate systemic hypotension and renal insufficiency. Spironolactone, an aldosterone antagonist that is of benefit in 
patients with left-heart failure, is also used by some experts to treat right-heart failure. Serum electrolytes and renal function should be monitored closely.

Hypoxemia is a pulmonary vasoconstrictor, and supplemental oxygen should be used to maintain an oxygen saturation greater than $90 \%$. Supplemental oxygen use is more controversial in patients with Eisenmenger complex but may decrease the need for phlebotomy and reduce the occurrence of neurologic complications (47).

Although not extensively studied in PAH, digitalis is sometimes used for refractory right ventricular failure (48). In addition, atrial flutter or other atrial dysrhythmias often complicate late-stage right-heart dysfunction, and digoxin may be useful for rate control.

\section{Vasodilator Testing and Calcium-Channel Blockers}

Patients with idiopathic PAH who respond to vasodilators in the short term have improved survival with longterm use of calcium-channel blockers $(46,49)$. Various short-acting agents, including intravenous epoprostenol or adenosine and inhaled nitric oxide, have been used to test short-term response to vasodilators $(50,51)$. The recently formulated consensus definition of a positive short-term response to vasodilators in $\mathrm{PAH}$ is a decrease of at least 10 $\mathrm{mm} \mathrm{Hg}$ in mean pulmonary arterial pressure to $40 \mathrm{~mm} \mathrm{Hg}$ or less, with increased or unchanged cardiac output (43, 44). Most experts feel that true vasoreactivity is uncommon, occurring in approximately $10 \%$ of patients with idiopathic PAH and rarely in other forms of PAH. Vasoreactivity testing should be done in experienced centers.

Only patients who have a substantial response to a short-acting vasodilator should be considered candidates for treatment with oral calcium-channel blockers; treatment should be monitored closely because maintenance of response is not universal. Agents with negative inotropic effects, such as verapamil, should be avoided.

\section{Prostanoids}

Prostacyclin is a metabolite of arachidonic acid produced in vascular endothelium. It is a potent vasodilator, affecting both the pulmonary and systemic circulations, and has antiplatelet aggregator effects. A relative deficiency of endogenous prostacyclin may contribute to the pathogenesis of PAH $(52,53)$.

In idiopathic $\mathrm{PAH}$, continuous intravenous infusion of epoprostenol improved exercise capacity, as assessed by the 6-min walk test; cardiopulmonary hemodynamic variables; and survival compared with conventional therapy (such as oral vasodilators and anticoagulation) (54). A similar study (55) showed that epoprostenol improved exercise capacity and hemodynamic variables in patients with PAH due to the scleroderma spectrum of disease. The beneficial effects of epoprostenol therapy are sustained for years in many patients with idiopathic PAH (56-59), and epoprostenol therapy remains the treatment of choice for the most severely ill patients.

Epoprostenol therapy is complicated by the need for continuous intravenous infusion. Because epoprostenol has a short half-life and has irritant effects on peripheral veins, and because of the risk for rebound worsening with interruption of the infusion, the drug should be administered through an indwelling central venous catheter. Common side effects include headache, flushing, jaw pain, diarrhea, nausea, a blotchy erythematous rash, and musculoskeletal pain. Acute overdose can lead to systemic hypotension, and long-term overdosage can produce a hyperdynamic circulatory state with high-output cardiac failure (60). Serious complications include catheter-related sepsis and thrombosis. Although epoprostenol is approved by the U.S. Food and Drug Administration for patients in functional NYHA class III and IV with idiopathic PAH or PAH due to scleroderma, it is generally reserved for those with advanced disease refractory to oral therapies. Because of its complexity, epoprostenol therapy should be given in centers experienced with its administration.

Beraprost is an orally active prostacyclin analogue (61). In a 12-week trial done in patients with $\mathrm{PAH}$ in NYHA functional class II and III, beraprost increased the 6-min walking distance without substantially affecting cardiopulmonary hemodynamic variables or survival (62). However, a longer-term trial (63) found that improvement was not present after 9 to 12 months. Beraprost is approved for treatment of PAH in Japan.

Treprostinil is a stable prostacyclin analogue with a half-life of 3 hours, and it can be administered subcutaneously or intravenously. In a multicenter study of subcutaneously infused treprostinil in patients with PAH (64), 6-min walking distance and hemodynamic variables improved modestly with treprostinil compared with placebo. Common side effects include pain at the infusion site, headache, diarrhea, nausea, rash, and jaw pain. Treprostinil is approved by the U.S. Food and Drug Administration for subcutaneous or intravenous treatment of patients with PAH in NYHA functional class II, III, and IV and is generally used when oral therapy has failed to produce benefit. To receive treprostinil therapy, patients should be referred to experienced centers.

Iloprost is a stable prostacyclin analogue with a serum half-life of 20 to 25 minutes. Although it may be possible to administer iloprost intravenously, the drug has gained attention recently for delivery by inhalation. In idiopathic $\mathrm{PAH}$, short-term inhalation of iloprost resulted in greater pulmonary vasodilatation than did nitric oxide (65). For long-term use, the relatively short duration of action of inhaled iloprost necessitates 6 to 9 inhalations per day (66, 67). In a 3-month multicenter trial, iloprost administered in a dosage of 2.5 or $5 \mu \mathrm{g} 6$ or 9 times daily improved the 6-min walking distance and NYHA functional class (68). Hemodynamic variables measured after iloprost inhalation were also improved at 3 months. Cough, flushing, and headache occurred more frequently in the iloprost group than in the group receiving placebo. Inhaled iloprost may be useful as an adjunct to oral therapy. It is approved in 
REVIEW Evaluation and Management of the Patient with Pulmonary Arterial Hypertension

Europe for patients with idiopathic PAH in NYHA functional class III and was recently approved by the U.S. Food and Drug Administration for patients with PAH in NYHA functional class III and IV.

\section{Endothelin-Receptor Antagonists}

Endothelin-1 is a potent vasoconstrictor and smoothmuscle mitogen that may contribute to increased vascular tone and proliferation in PAH (69). Endothelin-1 expression, production, and concentration in plasma (70) and lung tissue (71) are elevated in $\mathrm{PAH}$, and levels correlate with disease severity (72). Two endothelin-receptor isoforms, endothelin-A (ETA) and endothelin-B (ETB), have been identified. Activation of ETA receptors facilitates vasoconstriction and proliferation of vascular smooth-muscle cell. The ETB receptors are thought to be principally involved in the clearance of endothelin, particularly in the vascular beds of the lung and kidney. Activation of ETB receptors may also cause vasodilatation and nitric oxide release. Whether it is preferable to block both ETA and ETB receptors or to selectively target ETA receptors is controversial. It has been argued that selective ETA-receptor antagonism may be beneficial for the treatment of PAH because of maintenance of the vasodilator and clearance functions of ETB receptors.

A multicenter study of bosentan, a dual ETA/ETBreceptor antagonist, showed a mean change of $76 \mathrm{~m}$ in 6-min walking distance (73). Bosentan also improved cardiopulmonary hemodynamic variables and NYHA functional class compared with placebo. Asymptomatic increases in hepatic aminotransferase levels were seen in 2 bosentan-treated patients, but the levels normalized without discontinuation of therapy or change of dose.

Similar improvement in exercise capacity, alleviation of symptoms, and alleviation of clinical worsening were seen in a larger multicenter study (74). Because of the risk for hepatotoxicity, the U.S. Food and Drug Administration requires that liver function tests be done at least monthly. Bosentan may also cause anemia, edema, and teratogenicity. The endothelin antagonists as a class may produce testicular atrophy and male infertility. Bosentan is approved in the United States for patients with PAH in NYHA class III and IV and in Europe for those in NYHA class III. Two selective ETA-receptor antagonists, sitaxsentan and ambrisentan, are currently in phase III clinical trials and remain investigational agents (75).

\section{Phosphodiesterase-5 Inhibitors}

The effects of nitric oxide, a pulmonary arterial vasodilator, depend on its augmentation of cyclic guanosine monophosphate (cGMP) content in vascular smooth muscle. The effects of intracellular cGMP are short-lived because of the rapid degradation of cGMP by phosphodiesterases $(76,77)$. Phosphodiesterase-5 is strongly expressed in the lung, and its gene expression and activity are increased in chronic pulmonary hypertension (78). Drugs that selectively inhibit cGMP-specific phosphodiesterase (type 5 inhibitors) augment the pulmonary vascular response to endogenous or inhaled nitric oxide in models of pulmonary hypertension $(79,80)$.

Sildenafil is a highly specific phosphodiesterase- 5 inhibitor currently approved for erectile dysfunction. Sildenafil reduces pulmonary arterial pressure in patients with PAH in the short term (81) and both augments and prolongs the effects of inhaled nitric oxide $(81,82)$, preventing rebound pulmonary vasoconstriction after withdrawal of nitric oxide (83). The combination of sildenafil and aerosolized iloprost caused a greater, more prolonged decrease in pulmonary vascular resistance than did either agent alone (84). Several single-center, nonrandomized studies of patients with PAH treated with long-term sildenafil therapy are promising (85-88). A multicenter clinical trial was recently completed and presented in abstract form (89). Sildenafil has recently been approved by the U.S. Food and Drug Administration for use in PAH.

The patient began receiving oral bosentan, $62.5 \mathrm{mg}$ twice daily, and the dosage was titrated to $125 \mathrm{mg}$ twice daily after 1 month. An echocardiogram 3 months later showed an estimated pulmonary arterial systolic pressure of $55 \mathrm{~mm} \mathrm{Hg}$, and results of the 6-min walk test had increased by $35 \mathrm{~m}$. The patient reported less dyspnea and greater activity tolerance. She saw her specialist every 3 months and had follow-up visits with her primary care physician. Two years after starting bosentan therapy, the patient reported gradually worsening fatigue, dyspnea on exertion, ankle edema, and an episode of near-syncope. The 6-min walk test results were slightly worse compared with baseline, and right-heart catheterization showed a pulmonary arterial pressure of 75/36 mm Hg (mean, $48 \mathrm{~mm} \mathrm{Hg}$ ). Right atrial pressure was $13 \mathrm{~mm} \mathrm{Hg}$, pulmonary capillary wedge pressure was $7 \mathrm{~mm} \mathrm{Hg}$, and cardiac output was $2.7 \mathrm{~L} / \mathrm{min}$. An indwelling central venous catheter was placed, and longterm intravenous epoprostenol therapy was initiated. Although relatively little evidence supports combined use of bosentan and epoprostenol, bosentan treatment was continued during the initiation of epoprostenol therapy. The patient also began receiving diuretic therapy and was referred for evaluation for lung transplantation. Eighteen months later, fatigue had lessened, ankle edema had resolved, and the 6-min walking distance was $330 \mathrm{~m}$. The patient decided not to pursue lung transplantation at this time.

\section{Interventional and Surgical Therapies}

Atrial septostomy involves the creation of a right-toleft interatrial shunt to decompress the failing pressureand volume-overloaded right heart (90). Where advanced medical therapies are available, atrial septostomy is seen largely as a palliative procedure or as a stabilizing bridge to lung transplantation (91). In regions of the world lacking access to advanced medical therapies, atrial septostomy may be the best treatment option available (92). Patient selection, timing, and appropriate sizing of the septostomy are crucial to optimizing outcomes. 
Table 3. Indications for Referral to a Specialized Center for Treatment of Pulmonary Arterial Hypertension*

Unexplained dyspnea on exertion with evidence of $\mathrm{PAH}$ on echocardiography

Evidence of moderate to severe $\mathrm{PAH}$

Estimated pulmonary arterial systolic pressure $>45 \mathrm{~mm} \mathrm{Hg}$ on echocardiography

Symptoms consistent with New York Heart Association functional class II Near-syncope or syncope

Absence of substantial left-sided cardiac disease or parenchymal lung disease

Clinical or echocardiographic evidence of right ventricular dysfunction Lower-extremity edema

Ascites

Right ventricular enlargement or systolic dysfunction on echocardiography

* $\mathrm{PAH}=$ pulmonary arterial hypertension.

Lung transplantation is particularly challenging in $\mathrm{PAH}$ (93) and is usually reserved for patients whose conditions are deteriorating despite the best available medical therapy. Survival in patients with PAH having lung transplantation is approximately $66 \%$ to $75 \%$ at 1 year (94). Most centers prefer bilateral lung transplantation for patients with PAH (95).

The development of treatments for $\mathrm{PAH}$ has created the challenge of how best to monitor the effects of longterm therapy. Noninvasive markers of disease severity, such as results on the 6-min walk test and assessment of NYHA functional class, are useful in identifying stability or deterioration (96). Echocardiographic indices of right-heart size and function may also be useful in noninvasive monitoring of therapy. Repeated cardiac catheterization may be a good option when noninvasive measures suggest deterioration and alternative therapies are being considered, because the choice of therapy may be governed by the severity of hemodynamic abnormality. Biomarkers, such as brain natriuretic peptide and troponin levels, or the results of physiologic studies, such as cardiopulmonary stress testing (96), are also being used to monitor clinical course.

\section{What Is the Role of the Primary Care Physician in the Management of the Patient With PAH?}

The importance of coordinated care by the general internist and the specialist cannot be overemphasized. Early recognition, diagnosis, and referral (Table 3) to a center with expertise in management of PAH can make a substantial difference in outcome. Specialized centers caring for patients with PAH are generally led by a cardiologist or pulmonologist, and a list of centers can be found on the Web site of the Pulmonary Hypertension Association (www.phassociation.org). Because of the special expertise required, referral centers often prefer to do the invasive procedures and initiate therapy. Long-term follow-up can be provided in both the internist's and the specialist's practice (Table 4). The internist can play an important role in monitoring the patient's fluid balance, electrolytes, renal function, liver test results, and levels of anticoagulation.
We generally recommend maintaining a euvolemic state in these patients. Peripheral edema, ascites, or marked jugular venous distention suggests right ventricular dysfunction and volume overload. Patients should regularly monitor body weight and contact their internist or pulmonary hypertension specialist if their weight increases by more than several pounds. Timely intervention limiting fluid and sodium intake, or adjusting diuretic dosing, may avert the need to hospitalize the patient to administer intravenous diuretics. Emergency care in the patient's home area may also be facilitated by a close relationship with an internist.

\section{Future Directions}

Considerable interest has been seen in combining therapeutic agents with different mechanisms of action, as has been done in the treatment of systemic hypertension and cancer. For example, phosphodiesterase inhibitors may enhance and prolong the effects of prostanoids. Such combinations offer the possibility of enhanced efficacy and may permit individual agents to be used in lower doses, minimizing toxicity. To date, only a few small studies of combination therapy have been done $(97,98)$.

Future studies targeting newly identified alterations in endothelial and smooth-muscle cell function, including vasoactive intestinal peptide synthesis and activity (99), angiopoeitin (100), and the serotonin pathway (101), may provide novel treatments.

Drugs that are currently marketed to treat other con-

Table 4. Roles of the Internist and the Specialist in the Diagnosis and Coordinated Care of Patients with Pulmonary Arterial Hypertension

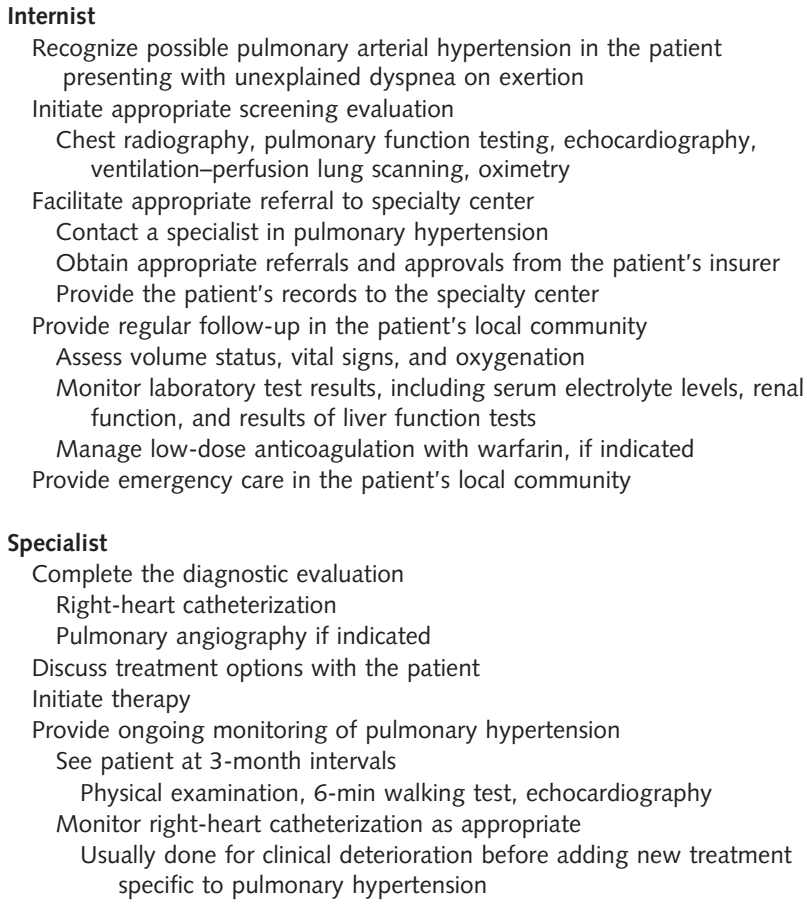
presenting with unexplained dyspnea on exertion 
REVIEW Evaluation and Management of the Patient with Pulmonary Arterial Hypertension

ditions may have beneficial effects in PAH. For example, the 3-hydroxy-3-methylglutaryl coenzyme A reductase inhibitors manifest pleiotropic effects that may be responsible for a component of their benefit in arteriosclerotic disease, and these agents attenuate pulmonary arteriopathy in animal models (102). Similarly, currently available platelet inhibitors (such as aspirin) and newer antithrombotic agents may have a role in the treatment of patients with $\mathrm{PAH}$, in light of the beneficial effects and inherent risks of anticoagulation with warfarin in these patients. Finally, given the important structural changes seen in severe PAH, inhibitors of vascular cellular proliferation and angiogenesis warrant clinical investigation.

From the University of California, San Diego, Medical Center, La Jolla, California; and University of Colorado Health Sciences Center, Denver, Colorado.

Acknowledgments: The authors thank their colleagues who participated in the 3rd World Symposium on Pulmonary Artery Hypertension and who served on the ACCP Evidence-Based Guidelines panel, from whose work they have drawn in the preparation of this manuscript.

Potential Financial Conflicts of Interest: Consultancies: L.J. Rubin (Actelion, Pfizer Inc., Schering, CoTherix, United Therapeutics, Myogen), D.B. Badesch (GlaxoWellcome/GlaxoSmithKline, Actelion, Berlex, Astra Merck, AstraZeneca, Myogen, Intermune, Forest Laboratories, Encysive, Exhale Therapeutics/CoTherix, Pfizer, Scios, MondoBiotech, PR Pharmaceuticals); Honoraria: L.J. Rubin (Actelion, Myogen), D.B. Badesch (Glaxo Wellcome/GlaxoSmithKline, Actelion, Pfizer Inc., Encysive, United Therapeutics); Stock ownership or options (other than mutual funds): D.B. Badesch (Johnson \& Johnson); Expert testimony: L.J. Rubin (Appetite suppressant litigation), D.B. Badesch (Appetite suppressant litigation); Grants received: L.J. Rubin (Actelion, Pfizer Inc., CoTherix, Myogen, National Institutes of Health), D.B. Badesch (Glaxo Wellcome/GlaxoSmithKline, United Therapeutics, Boehringer Ingelheim, Actelion, ICOS Corp./Texas Biotechnologies, Encysive, Pfizer Inc., Myogen, CoTherix, Lilly/ICOS, American Lung Association, American Heart Association, National Institutes of Health, Scleroderma Foundation).

Requests for Single Reprints: Lewis J. Rubin, MD, University of California, San Diego, Medical Center, 9300 Campus Point Drive, M/C 7381, La Jolla, CA 92037-7381.

Current author addresses are available at www.annals.org.

\section{References}

1. Diagnosis and management of pulmonary arterial hypertension: ACCP evidence-based clinical practice guideline. Chest. 2004;125(Suppl):1S-92S.

2. Rubin LJ. Primary pulmonary hypertension. N Engl J Med. 1997;336:111-7. [PMID: 8988890]

3. Thomson JR, Machado RD, Pauciulo MW, Morgan NV, Humbert M, Elliott GC, et al. Sporadic primary pulmonary hypertension is associated with germline mutations of the gene encoding BMPR-II, a receptor member of the TGF-beta family. J Med Genet. 2000;37:741-5. [PMID: 11015450]

4. McGoon M, Gutterman D, Steen V, Barst R, McCrory DC, Fortin TA, et al. Screening, early detection and diagnosis of pulmonary arterial hypertension: ACCP evidence-based clinical practice guidelines. Chest. 2004;126(Suppl):14S34S. [PMID: 15249493]

5. Battle RW, Davitt MA, Cooper SM, Buckley LM, Leib ES, Beglin PA, et al.
Prevalence of pulmonary hypertension in limited and diffuse scleroderma. Chest. 1996;110:1515-9. [PMID: 8989070]

6. Ungerer RG, Tashkin DP, Furst D, Clements PJ, Gong H Jr, Bein M, et al. Prevalence and clinical correlates of pulmonary arterial hypertension in progressive systemic sclerosis. Am J Med. 1983;75:65-74. [PMID: 6859087]

7. Tanaka E, Harigai M, Tanaka M, Kawaguchi Y, Hara M, Kamatani N. Pulmonary hypertension in systemic lupus erythematosus: evaluation of clinical characteristics and response to immunosuppressive treatment. J Rheumatol. 2002;29:282-7. [PMID: 11838845]

8. Fagan KA, Badesch DB. Pulmonary hypertension associated with connective tissue disease. In: Peacock AJ, Rubin LJ, eds. Pulmonary Circulation. London: Arnold Publishers; 2004:181-90.

9. Love PE, Santoro SA. Antiphospholipid antibodies: anticardiolipin and the lupus anticoagulant in systemic lupus erythematosus (SLE) and in non-SLE disorders. Relevance and clinical significance. Ann Intern Med. 1990;112:682-98. [PMID: 2110431]

10. Opravil M, Pechere M, Speich R, Joller-Jemelka HI, Jenni R, Russi EW, et al. HIV-associated primary pulmonary hypertension. A case control study. Swiss HIV Cohort Study. Am J Respir Crit Care Med. 1997;155:990-5. [PMID: 9117037]

11. Petitpretz P, Brenot F, Azarian R, Parent F, Rain B, Herve P, et al. Pulmonary hypertension in patients with human immunodeficiency virus infection. Comparison with primary pulmonary hypertension. Circulation. 1994;89: 2722-7. [PMID: 8205687]

12. Mehta NJ, Khan IA, Mehta RN, Sepkowitz DA. HIV-related pulmonary hypertension: analytic review of 131 cases. Chest. 2000;118:1133-41. [PMID: 11035689]

13. Gladwin MT, Sachdev V, Jison ML, Shizukuda Y, Plehn JF, Minter K, et al. Pulmonary hypertension as a risk factor for death in patients with sickle cell disease. N Engl J Med. 2004;350:886-95. [PMID: 14985486]

14. Kuo PC, Plotkin JS, Johnson LB, Howell CD, Laurin JM, Bartlett ST, et al. Distinctive clinical features of portopulmonary hypertension. Chest. 1997; 112:980-6. [PMID: 9377962]

15. Castro M, Krowka MJ, Schroeder DR, Beck KC, Plevak DJ, Rettke SR, et al. Frequency and clinical implications of increased pulmonary artery pressures in liver transplant patients. Mayo Clin Proc. 1996;71:543-51. [PMID: 8642882] 16. Rich S, Dantzker DR, Ayres SM, Bergofsky EH, Brundage BH, Detre KM, et al. Primary pulmonary hypertension. A national prospective study. Ann Intern Med. 1987;107:216-23. [PMID: 3605900]

17. Grunig E, Janssen B, Mereles D, Barth U, Borst MM, Vogt IR, et al. Abnormal pulmonary artery pressure response in asymptomatic carriers of primary pulmonary hypertension gene. Circulation. 2000;102:1145-50. [PMID: 10973844]

18. Abenhaim L, Moride Y, Brenot F, Rich S, Benichou J, Kurz X, et al. Appetite-suppressant drugs and the risk of primary pulmonary hypertension. International Primary Pulmonary Hypertension Study Group. N Engl J Med. 1996;335:609-16. [PMID: 8692238]

19. Rich S, Rubin L, Walker AM, Schneeweiss S, Abenhaim L. Anorexigens and pulmonary hypertension in the United States: results from the surveillance of North American pulmonary hypertension. Chest. 2000;117:870-4. [PMID: 10713017]

20. Fedullo PF, Auger WR, Kerr KM, Rubin LJ. Chronic thromboembolic pulmonary hypertension. N Engl J Med. 2001;345:1465-72. [PMID: 11794196]

21. Bossone E, Rubenfire M, Bach DS, Ricciardi M, Armstrong WF. Range of tricuspid regurgitation velocity at rest and during exercise in normal adult men: implications for the diagnosis of pulmonary hypertension. J Am Coll Cardiol. 1999;33:1662-6. [PMID: 10334439]

22. Brecker SJ, Gibbs JS, Fox KM, Yacoub MH, Gibson DG. Comparison of Doppler derived haemodynamic variables and simultaneous high fidelity pressure measurements in severe pulmonary hypertension. Br Heart J. 1994;72:384-9. [PMID: 7833199]

23. Denton CP, Cailes JB, Phillips GD, Wells AU, Black CM, Bois RM. Comparison of Doppler echocardiography and right heart catheterization to assess pulmonary hypertension in systemic sclerosis. Br J Rheumatol. 1997;36:23943. [PMID: 9133938]

24. Shapiro SM, Oudiz RJ, Cao T, Romano MA, Beckmann XJ, Georgiou D, et al. Primary pulmonary hypertension: improved long-term effects and survival with continuous intravenous epoprostenol infusion. J Am Coll Cardiol. 1997;30: 343-9. [PMID: 9247503] 
Evaluation and Management of the Patient with Pulmonary Arterial Hypertension $\mid$ REVIEW

25. Hinderliter AL, Willis PW 4th, Barst RJ, Rich S, Rubin LJ, Badesch DB, et al. Effects of long-term infusion of prostacyclin (epoprostenol) on echocardiographic measures of right ventricular structure and function in primary pulmonary hypertension. Primary Pulmonary Hypertension Study Group. Circulation. 1997;95:1479-86. [PMID: 9118516]

26. Morris TA, Auger WR, Ysrael MZ, Olson LK, Channick RN, Fedullo PF, et al. Parenchymal scarring is associated with restrictive spirometric defects in patients with chronic thromboembolic pulmonary hypertension. Chest. 1996; 110:399-403. [PMID: 8697841]

27. Owens GR, Fino GJ, Herbert DL, Steen VD, Medsger TA Jr, Pennock BE, et al. Pulmonary function in progressive systemic sclerosis. Comparison of CREST syndrome variant with diffuse scleroderma. Chest. 1983;84:546-50. [PMID: 6628005]

28. Steen V, Medsger TA Jr. Predictors of isolated pulmonary hypertension in patients with systemic sclerosis and limited cutaneous involvement. Arthritis Rheum. 2003;48:516-22. [PMID: 12571862]

29. Rafanan AL, Golish JA, Dinner DS, Hague LK, Arroliga AC. Nocturnal hypoxemia is common in primary pulmonary hypertension. Chest. 2001;120: 894-9. [PMID: 11555526]

30. Atwood CW Jr, McCrory D, Garcia JG, Abman SH, Ahearn GS. Pulmonary artery hypertension and sleep-disordered breathing: ACCP evidence-based clinical practice guidelines. Chest. 2004;126:72S-77S. [PMID: 15249496]

31. Azarian R, Wartski M, Collignon MA, Parent F, Herve P, Sors H, et al. Lung perfusion scans and hemodynamics in acute and chronic pulmonary embolism. J Nucl Med. 1997;38:980-3. [PMID: 9189155]

32. Ryan KL, Fedullo PF, Davis GB, Vasquez TE, Moser KM. Perfusion scan findings understate the severity of angiographic and hemodynamic compromise in chronic thromboembolic pulmonary hypertension. Chest. 1988;93:1180-5. [PMID: 3371097]

33. Bailey CL, Channick RN, Auger WR, Fedullo PF, Kerr KM, Yung GL, et al. "High probability" perfusion lung scans in pulmonary venoocclusive disease. Am J Respir Crit Care Med. 2000;162:1974-8. [PMID: 11069842]

34. King MA, Ysrael M, Bergin CJ. Chronic thromboembolic pulmonary hypertension: CT findings. AJR Am J Roentgenol. 1998;170:955-60. [PMID: 9530043]

35. Swensen SJ, Tashjian JH, Myers JL, Engeler CE, Patz EF, Edwards WD, et al. Pulmonary venoocclusive disease: CT findings in eight patients. AJR Am J Roentgenol. 1996;167:937-40. [PMID: 8819387]

36. Pietra GG, Capron F, Stewart S, Leone O, Humbert M, Robbins IM, et al. Pathologic assessment of vasculopathies in pulmonary hypertension. J Am Coll Cardiol. 2004;43(Suppl):25S-32S. [PMID: 15194175]

37. McCaffrey RN, Dunn LH. Primary pulmonary hypertension in pregnancy. Obstet Gynecol Surv. 1964;19:567-91. [PMID: 14179852]

38. Weiss BM, Zemp L, Seifert B, Hess OM. Outcome of pulmonary vascular disease in pregnancy: a systematic overview from 1978 through 1996. J Am Coll Cardiol. 1998;31:1650-7. [PMID: 9626847]

39. Elkayam U, Dave R, Bokhari SW. Primary pulmonary hypertension and pregnancy. In: Elkayam U, Gleivher N, eds. Cardiac Problems in Pregnancy. New York: Wiley-Liss; 1998:183-90.

40. Badalian SS, Silverman RK, Aubry RH, Longo J. Twin pregnancy in a woman on long-term epoprostenol therapy for primary pulmonary hypertension. A case report. J Reprod Med. 2000;45:149-52. [PMID: 10710749].

41. Stewart R, Tuazon D, Olson G, Duarte AG. Pregnancy and primary pulmonary hypertension: successful outcome with epoprostenol therapy. Chest. 2001;119:973-5. [PMID: 11243988]

42. Decoene C, Bourzoufi K, Moreau D, Narducci F, Crepin F, KrivosicHorber R. Use of inhaled nitric oxide for emergency Cesarean section in a woman with unexpected primary pulmonary hypertension. Can J Anaesth. 2001; 48:584-7. [PMID: 11444454]

43. Badesch DB, Abman SH, Ahearn GS, Barst RJ, McCrory DC, Simonneau G, et al. Medical therapy for pulmonary arterial hypertension: ACCP evidencebased clinical practice guidelines. Chest. 2004;126:35S-62S. [PMID: 15249494] 44. Galie N, Seeger W, Naeije R, Simonneau G, Rubin LJ. Comparative analysis of clinical trials and evidence-based treatment algorithm in pulmonary arterial hypertension. J Am Coll Cardiol. 2004;43:81S-88S. [PMID: 15194183] 45. Fuster V, Steele PM, Edwards WD, Gersh BJ, McGoon MD, Frye RL. Primary pulmonary hypertension: natural history and the importance of thrombosis. Circulation. 1984;70:580-7. [PMID: 6148159]

46. Rich S, Kaufmann E, Levy PS. The effect of high doses of calcium-channel blockers on survival in primary pulmonary hypertension. N Engl J Med. 1992;
327:76-81. [PMID: 1603139]

47. Sandoval J, Aguirre JS, Pulido T, Martinez-Guerra ML, Santos E, Alvarado $\mathrm{P}$, et al. Nocturnal oxygen therapy in patients with the Eisenmenger syndrome. Am J Respir Crit Care Med. 2001;164:1682-7. [PMID: 11719310]

48. Rich S, Seidlitz M, Dodin E, Osimani D, Judd D, Genthner D, et al. The short-term effects of digoxin in patients with right ventricular dysfunction from pulmonary hypertension. Chest. 1998;114:787-92. [PMID: 9743167]

49. Ogata M, Ohe M, Shirato K, Takishima T. Effects of a combination therapy of anticoagulant and vasodilator on the long-term prognosis of primary pulmonary hypertension. Jpn Circ J. 1993;57:63-9. [PMID: 8437343]

50. Sitbon O, Brenot F, Denjean A, Bergeron A, Parent F, Azarian R, et al. Inhaled nitric oxide as a screening vasodilator agent in primary pulmonary hypertension. A dose-response study and comparison with prostacyclin. Am J Respir Crit Care Med. 1995;151:384-9. [PMID: 7842196]

51. Schrader BJ, Inbar S, Kaufmann L, Vestal RE, Rich S. Comparison of the effects of adenosine and nifedipine in pulmonary hypertension. J Am Coll Cardiol. 1992;19:1060-4. [PMID: 1552096]

52. Christman BW, McPherson CD, Newman JH, King GA, Bernard GR, Groves BM, et al. An imbalance between the excretion of thromboxane and prostacyclin metabolites in pulmonary hypertension. N Engl J Med. 1992;327: 70-5. [PMID: 1603138]

53. Tuder RM, Cool CD, Geraci MW, Wang J, Abman SH, Wright L, et al. Prostacyclin synthase expression is decreased in lungs from patients with severe pulmonary hypertension. Am J Respir Crit Care Med. 1999;159:1925-32. [PMID: 10351941]

54. Barst RJ, Rubin LJ, Long WA, McGoon MD, Rich S, Badesch DB, et al. A comparison of continuous intravenous epoprostenol (prostacyclin) with conventional therapy for primary pulmonary hypertension. The Primary Pulmonary Hypertension Study Group. N Engl J Med. 1996;334:296-302. [PMID: 8532025]

55. Badesch DB, Tapson VF, McGoon MD, Brundage BH, Rubin LJ, Wigley FM, et al. Continuous intravenous epoprostenol for pulmonary hypertension due to the scleroderma spectrum of disease. A randomized, controlled trial. Ann Intern Med. 2000;132:425-34. [PMID: 10733441]

56. Barst RJ, Rubin LJ, McGoon MD, Caldwell EJ, Long WA, Levy PS. Survival in primary pulmonary hypertension with long-term continuous intravenous prostacyclin. Ann Intern Med. 1994;121:409-15. [PMID: 8053614]

57. Shapiro SM, Oudiz RJ, Cao T, Romano MA, Beckmann XJ, Georgiou D, et al. Primary pulmonary hypertension: improved long-term effects and survival with continuous intravenous epoprostenol infusion. J Am Coll Cardiol. 1997;30: 343-9. [PMID: 9247503]

58. McLaughlin VV, Shillington A, Rich S. Survival in primary pulmonary hypertension: the impact of epoprostenol therapy. Circulation. 2002;106:147782. [PMID: 12234951]

59. Sitbon O, Humbert M, Nunes H, Parent F, Garcia G, Herve P, et al. Long-term intravenous epoprostenol infusion in primary pulmonary hypertension: prognostic factors and survival. J Am Coll Cardiol. 2002;40:780-8. [PMID: 12204511]

60. Rich S, McLaughlin VV. The effects of chronic prostacyclin therapy on cardiac output and symptoms in primary pulmonary hypertension. J Am Coll Cardiol. 1999;34:1184-7. [PMID: 10520810]

61. Okano Y, Yoshioka T, Shimouchi A, Satoh T, Kunieda T. Orally active prostacyclin analogue in primary pulmonary hypertension [Letter]. Lancet. 1997; 349:1365. [PMID: 9149701]

62. Galie N, Humbert M, Vachiery JL, Vizza CD, Kneussl M, Manes A, et al. Effects of beraprost sodium, an oral prostacyclin analogue, in patients with pulmonary arterial hypertension: a randomized, double-blind, placebo-controlled trial. J Am Coll Cardiol. 2002;39:1496-502. [PMID: 11985913]

63. Barst RJ, McGoon M, McLaughlin V, Tapson V, Rich S, Rubin L, et al. Beraprost therapy for pulmonary arterial hypertension. J Am Coll Cardiol. 2003; 41:2119-25. [PMID: 12821234]

64. Simonneau G, Barst RJ, Galie N, Naeije R, Rich S, Bourge RC, et al. Continuous subcutaneous infusion of treprostinil, a prostacyclin analogue, in patients with pulmonary arterial hypertension: a double-blind, randomized, placebo-controlled trial. Am J Respir Crit Care Med. 2002;165:800-4. [PMID: 11897647]

65. Hoeper MM, Olschewski H, Ghofrani HA, Wilkens H, Winkler J, Borst $\mathrm{MM}$, et al. A comparison of the acute hemodynamic effects of inhaled nitric oxide and aerosolized iloprost in primary pulmonary hypertension. German PPH Study Group. J Am Coll Cardiol. 2000;35:176-82. [PMID: 10636277] 
REVIEW Evaluation and Management of the Patient with Pulmonary Arterial Hypertension

66. Olschewski H, Ghofrani HA, Schmehl T, Winkler J, Wilkens H, Hoper $\mathrm{MM}$, et al. Inhaled iloprost to treat severe pulmonary hypertension. An uncontrolled trial. German PPH Study Group. Ann Intern Med. 2000;132:435-43. [PMID: 10733442]

67. Hoeper MM, Schwarze M, Ehlerding S, Adler-Schuermeyer A, Spiekerkoetter E, Niedermeyer J, et al. Long-term treatment of primary pulmonary hypertension with aerosolized iloprost, a prostacyclin analogue. N Engl J Med. 2000;342:1866-70. [PMID: 10861321]

68. Olschewski H, Simonneau G, Galie N, Higenbottam T, Naeije R, Rubin LJ, et al. Inhaled iloprost for severe pulmonary hypertension. N Engl J Med. 2002;347:322-9. [PMID: 12151469]

69. Kim H, Yung GL, Marsh JJ, Konopka RG, Pedersen CA, Chiles PG, et al. Endothelin mediates pulmonary vascular remodelling in a canine model of chronic embolic pulmonary hypertension. Eur Respir J. 2000;15:640-8. [PMID: 10780753]

70. Rubens C, Ewert R, Halank M, Wensel R, Orzechowski HD, Schultheiss $\mathrm{HP}$, et al. Big endothelin-1 and endothelin-1 plasma levels are correlated with the severity of primary pulmonary hypertension. Chest. 2001;120:1562-9. [PMID: 11713135]

71. Giaid A, Yanagisawa M, Langleben D, Michel RP, Levy R, Shennib H, et al. Expression of endothelin-1 in the lungs of patients with pulmonary hypertension. N Engl J Med. 1993;328:1732-9. [PMID: 8497283]

72. Galie N, Grigioni F, Bacchi-Reggiani L, et al. Relation of endothelin-1 to survival in patients with primary pulmonary hypertension. Eur J Clin Invest. 1996;26:273.

73. Channick RN, Simonneau G, Sitbon O, Robbins IM, Frost A, Tapson VF, et al. Effects of the dual endothelin-receptor antagonist bosentan in patients with pulmonary hypertension: a randomised placebo-controlled study. Lancet. 2001; 358:1119-23. [PMID: 11597664]

74. Rubin LJ, Badesch DB, Barst RJ, Galie N, Black CM, Keogh A, et al. Bosentan therapy for pulmonary arterial hypertension. N Engl J Med. 2002;346: 896-903. [PMID: 11907289]

75. Barst RJ, Langleben D, Frost A, Horn EM, Oudiz R, Shapiro S, et al. Sitaxsentan therapy for pulmonary arterial hypertension. Am J Respir Crit Care Med. 2004;169:441-7. [PMID: 14630619]

76. Beavo JA, Reifsnyder DH. Primary sequence of cyclic nucleotide phosphodiesterase isozymes and the design of selective inhibitors. Trends Pharmacol Sci. 1990;11:150-5. [PMID: 2159198]

77. Ahn HS, Foster M, Cable M, Pitts BJ, Sybertz EJ. Ca/CaM-stimulated and cGMP-specific phosphodiesterases in vascular and non-vascular tissues. Adv Exp Med Biol. 1991;308:191-7. [PMID: 1666264]

78. Braner DA, Fineman JR, Chang R, Soifer SJ. M\&B 22948, a cGMP phosphodiesterase inhibitor, is a pulmonary vasodilator in lambs. Am J Physiol. 1993;264:H252-8. [PMID: 8381611]

79. Cohen AH, Hanson K, Morris K, Fouty B, McMurty IF, Clarke W, et al. Inhibition of cyclic 3'-5'-guanosine monophosphate-specific phosphodiesterase selectively vasodilates the pulmonary circulation in chronically hypoxic rats. J Clin Invest. 1996;97:172-9. [PMID: 8550830]

80. Hanson KA, Ziegler JW, Rybalkin SD, Miller JW, Abman SH, Clarke WR. Chronic pulmonary hypertension increases fetal lung cGMP phosphodiesterase activity. Am J Physiol. 1998;275:L931-41. [PMID: 9815111]

81. Michelakis E, Tymchak W, Lien D, Webster L, Hashimoto K, Archer S. Oral sildenafil is an effective and specific pulmonary vasodilator in patients with pulmonary arterial hypertension: comparison with inhaled nitric oxide. Circulation. 2002;105:2398-403. [PMID: 12021227]

82. Lepore JJ, Maroo A, Pereira NL, Ginns LC, Dec GW, Zapol WM, et al. Effect of sildenafil on the acute pulmonary vasodilator response to inhaled nitric oxide in adults with primary pulmonary hypertension. Am J Cardiol. 2002;90: 677-80. [PMID: 12231108]

83. Atz AM, Wessel DL. Sildenafil ameliorates effects of inhaled nitric oxide withdrawal. Anesthesiology. 1999;91:307-10. [PMID: 10422958]

84. Wilkens H, Guth A, Konig J, Forestier N, Cremers B, Hennen B, et al. Effect of inhaled iloprost plus oral sildenafil in patients with primary pulmonary hypertension. Circulation. 2001;104:1218-22. [PMID: 11551870] 85. Ghofrani HA, Wiedemann R, Rose F, Olschewski H, Schermuly RT, Weissmann N, et al. Combination therapy with oral sildenafil and inhaled iloprost for severe pulmonary hypertension. Ann Intern Med. 2002;136:515-22. [PMID: 11926786]

86. Sastry BK, Narasimhan C, Reddy NK, Raju BS. Clinical efficacy of sildenafil in primary pulmonary hypertension: a randomized, placebo-controlled, double-blind, crossover study. J Am Coll Cardiol. 2004;43:1149-53. [PMID: 15063421]

87. Bharani A, Mathew V, Sahu A, Lunia B. The efficacy and tolerability of sildenafil in patients with moderate-to-severe pulmonary hypertension. Indian Heart J. 2003;55:55-9. [PMID: 12760589]

88. Ghofrani HA, Schermuly RT, Rose F, Wiedemann R, Kohstall MG, Kreckel A, et al. Sildenafil for long-term treatment of nonoperable chronic thromboembolic pulmonary hypertension. Am J Respir Crit Care Med. 2003; 167:1139-41. [PMID: 12684251]

89. Ghofrani HA, Barst J, Badesch DB, Burgess G, Fleming T, Galie N, et al. Sildenafil use in pulmonary arterial hypertension: a multinational, randomized, double-blind, placebo-controlled trial. Chest. 2004 [Abstract].

90. Sandoval J, Rothman A, Pulido T. Atrial septostomy for pulmonary hypertension. Clin Chest Med. 2001;22:547-60. [PMID: 11590848]

91. Rothman A, Sklansky MS, Lucas VW, Kashani IA, Shaughnessy RD, Channick RN, et al. Atrial septostomy as a bridge to lung transplantation in patients with severe pulmonary hypertension. Am J Cardiol. 1999;84:682-6. [PMID: 10498139]

92. Sandoval J, Gaspar J, Pulido T, Bautista E, Martínez-Guerra ML, Zeballos M, et al. Graded balloon dilation atrial septostomy in severe primary pulmonary hypertension. A therapeutic alternative for patients nonresponsive to vasodilator treatment. J Am Coll Cardiol. 1998;32:297-304. [PMID: 9708453]

93. Christie JD, Kotloff RM, Pochettino A, Arcasoy SM, Rosengard BR, Landis JR, et al. Clinical risk factors for primary graft failure following lung transplantation. Chest. 2003;124:1232-41. [PMID: 14555551]

94. Mendeloff EN, Meyers BF, Sundt TM, Guthrie TJ, Sweet SC, de la Morena $\mathrm{M}$, et al. Lung transplantation for pulmonary vascular disease. Ann Thorac Surg. 2002;73:209-1799. [PMID: 11834012]

95. Pielsticker EJ, Martinez FJ, Rubenfire M. Lung and heart-lung transplant practice patterns in pulmonary hypertension centers. J Heart Lung Transplant. 2001;20:1297-304. [PMID: 11744413]

96. Hoeper MM, Oudiz RJ, Peacock A, Tapson VF, Haworth SG, Frost AE, et al. End points and clinical trial designs in pulmonary arterial hypertension: clinical and regulatory perspectives. J Am Coll Cardiol. 2004;43:48S-55S. [PMID: 15194178]

97. Hoeper MM, Taha N, Bekjarova A, Gatzke R, Spiekerkoetter E. Bosentan treatment in patients with primary pulmonary hypertension receiving nonparenteral prostanoids. Eur Respir J. 2003;22:330-4. [PMID: 12952269]

98. Humbert M, Barst RJ, Robbins IM, Channick RN, Galie N, Boonstra A, et al. Combination of bosentan with epoprostenol in pulmonary arterial hypertension: BREATHE-2. Eur Respir J. 2004;24:353-9. [PMID: 15358690]

99. Petkov V, Mosgoeller W, Ziesche R, Raderer M, Stiebellehner L, Vonbank $\mathrm{K}$, et al. Vasoactive intestinal peptide as a new drug for treatment of primary pulmonary hypertension. J Clin Invest. 2003;111:1339-46. [PMID: 12727925] 100. Du L, Sullivan CC, Chu D, Cho AJ, Kido M, Wolf PL, et al. Signaling molecules in nonfamilial pulmonary hypertension. N Engl J Med. 2003;348: 500-9. [PMID: 12571257]

101. Eddahibi S, Humbert M, Fadel E, Raffestin B, Darmon M, Capron F, et al. Serotonin transporter overexpression is responsible for pulmonary artery smooth muscle hyperplasia in primary pulmonary hypertension. J Clin Invest. 2001;108:1141-50. [PMID: 11602621]

102. Nishimura T, Vaszar LT, Faul JL, Zhao G, Berry GJ, Shi L, et al. Simvastatin rescues rats from fatal pulmonary hypertension by inducing apoptosis of neointimal smooth muscle cells. Circulation. 2003;108:1640-5. [PMID: 12963647] 
Current Author Addresses: Dr. Rubin: University of California, San Diego, Medical Center, 9300 Campus Point Drive, La Jolla, CA $92037-$ 7381.
Dr. Badesch: University of Colorado Health Sciences Center, Box C-272, 4200 East Ninth Avenue, Denver, CO 80262. 